\section{End now in sight for Gallo investigation?}

\section{- NIH inquiry narrows its focus - Doubts remain in Congress}

\section{Washington, Paris \& London}

SOURCES close to the misconduct probe of prominent AIDS researcher Robert Gallo say that, with last week's announcement that officials at the National Institutes of Health (NIH) have found no substance to some of the most serious allegations of misconduct, the investigation is "virtually over".

Were NIH the only interested party, that might well be the case. But Congress, in the form of Representative John Dingell (Democrat, Michigan), the powerful government watchdog who has put pressure on NIH throughout the ten-month inquiry, may not be as easily satisfied. "Dingell will not stop this until all the questions are answered", says Peter Stockton, a staff member of Dingell's Energy and Commerce Investigations subcommittee. A meeting this week between NIH officials and subcommittee staff may decide whether Dingell will move from being an observer to a participant by holding hearings on the case.

One of the questions Dingell will want answered is why NIH have chosen to focus exclusively on issues surrounding two papers published in Science by Gallo's laboratory in May 1984 (see Nature 347. $502 ; 11$ October 1990). In the Chicago Tribune article published last November that stimulated the NIH inquiry, reporter John Crewdson raised questions about Gallo's statements in the government's application for a patent on the first AIDS test, in correspondence with other researchers, and in public addresses, as well as in the Science papers.

William Raub, acting director of NIH, says investigators are "concentrating only on the reports in the refereed literature" to keep the probe "at the heart of what $\mathrm{NIH}$ does". "At this point we have decided not to concentrate on statements to the public", he says. If convincing evidence of misconduct arises from what is left of the investigation (mostly minor questions of wording and absent data in the papers), NIH may expand the probe, he says. "We don't expect that a major concentration of [other communications] will be useful at this point. We deliberately did not define the patent to be within the scope of the OSI investigation. Once the final report comes out, HHS [the Department of Health and Human Services, which runs NIH] may want to address that."

Raub stresses that although the charge of missing data is still worrying, "when one goes back 5-10 years one has to

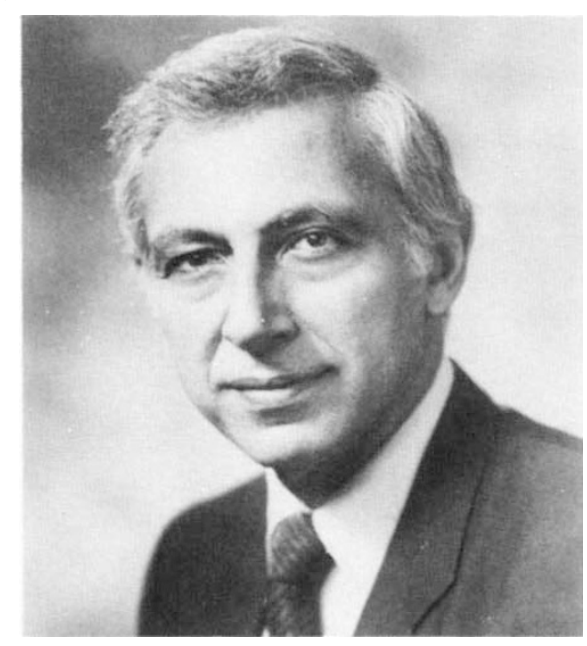

Gallo's ordeal nearly over?

make allowance for a different attitude". Several recent misconduct cases have forced NIH to establish more stringent standards of record-keeping.

As for the most serious allegation that Gallo "stole" the virus from the Parisbased Institut Pasteur, Raub is satisfied for the moment. "The question of misappropriation is not on the table", he says, although he adds that it could reappear should new evidence materialize. "For those who have alleged he had nothing [at the time], the evidence is that he had other viruses. There is no obvious motive" for intentionally taking LAV, the French virus, he says, adding that the overall conclusions of the four seminal Science papers are not in doubt. In the remaining points of the investigation "we have an apparent mismatch between the work as described and the work as done", he says. "But none of that challenges that final outcome of the work."

Jean-Claude Chermann, the former director of the Institut Pasteur, says he is satisfied that Gallo "had enough isolates not to need LAV". Although he still has questions about Gallo's techniques, he is ready to see the dispute end. "I just want it to stop so we can get on with the science", he says. Luc Montagnier, discoverer of the French virus, describes the NIH investigation as an "American affair" and says he has nothing to add to the 1987 agreement he entered into with Gallo.

Without more data (Gallo's lawyer, Joseph Onek, says NIH have all the records from the laboratory during the key period), Raub says that it is "a fair presumption" that investigators may never know what happened in Gallo's laboratory in late 1983 and early 1984, the key period before the Science papers were published.

At the moment, the most likely scenario for those months appears to be a story of contamination and confusion. Gallo concedes that, given that the French virus LAV and his own HTLV-IIIB are virtual genetic twins, it is possible that they were derived from the same sources. Although $\mathrm{NIH}$ investigators will try to trace the original viruses that were in his laboratory in 1983 and 1984, the odds that one of them should turn out to be an independently isolated copy of LAV appear slim (see Nature 347, 3 \& 18; 6 September 1990).

That leaves laboratory contamination as the most likely source of the virus. Assuming that possibility, and given that Gallo says his chief virologist, Mikulas Popovik, kept almost no notes during the experiments, misstatements in published articles and public forums may have been inevitable. That those misstatements tended to favour a scenario in which HTLV-IIIB was an independent discovery of Gallo's laboratory may not be legitimate grounds for further investigation.

Bolstering the contamination theory is evidence that LAV has emerged unexpectedly in other laboratories around the world. Robin Weiss of the Institute of Cancer Research in London says that in 1985, when he was attempting to make new viral isolates in a laboratory where LAV was being grown, it was LAV that first emerged.

"In my opinion it's all over", says a source close to the investigation who has seen the laboratory data. "It could have been a contamination, but who cares?" Given the state of the science at the time, he says the distinction between the "continuous" growth of the virus in T cells that Gallo has claimed in the Science papers, and the intermittent growth that his records show, is academic. Gallo's laboratory "had 25 to 50 isolates growing", he says. "They weren't completely sustainable, but neither were anybody else's."

But even if NIH find no evidence of misconduct, and Dingell is satisfied that the investigation was conducted properly, broader questions raised in Crewdson's article and in the July issue of the New York-based satirical magazine Spy may still remain. Crewdson's and Spy author Seth Robert's stories of backstabbing and deceit have painted a dim portrait of the AIDS research community. Roberts darkly hints that such activities have drawn attention from the very top. In a speech earlier this year, Pope John Paul II lashed out at "self-interested rivalries in the search for a medical answer" to the AIDS epidemic. But short of divine intervention, further investigation of AIDS researchers may be left to gossip magazines.

Christopher Anderson, Peter Coles \& David Concar 